\title{
ATITUDES, CRENÇAS E (AUTO)AVALIAÇÃO LINGUÍSTICA DE COMUNIDADES RURAIS DO 3ㅇ DISTRITO DE NOVA FRIBURGO
}

\author{
Jaqueline de Moraes Thurler Dália (IFF)
}

RESUMO: Este artigo é parte da tese que investigou, no âmbito da Sociolinguística, a variedade dialetal das comunidades rurais do 3 은 Distrito de Nova Friburgo, partindo da hipótese de que nela havia uma arquicomunidade de fala (ECKERT; MCCONNELL-GINET, 2010). Seu objetivo se concentra em compreender como os próprios falantes avaliam a sua variedade e como a veem frente a outra considerada de prestígio (LABOV, 2008; CARDOSO, 2015), levando em conta que o julgamento linguístico é carregado de valores simbólicos que contribuem para a valorização ou para a estigmatização de um grupo de falantes. Para tanto, foram realizadas 39 entrevistas com moradores, sendo 19 da faixa etária 1 (entre 35 e 50 anos) e 20 da faixa etária 2 (entre 14 e 18 anos); 20 mulheres e 19 homens. Os resultados demonstraram que a juventude domina mais de um código oral e tenta acioná-los de acordo com o contexto enunciativo. Isso aponta para duas conclusões: a geração mais nova, se não domina todas as regras da língua padrão, ao menos reconhece o ambiente em que sua variedade é aceita e conhece os mecanismos para adequar sua fala, mesmo que não consiga êxito em todas as suas realizações; e, se há problemas com a aceitabilidade dessa variedade é porque ela sofre preconceito. Assim, como provavelmente os mais velhos foram os que mais ficaram expostos a avaliação negativa de fala, eles reproduzem a estigmatização que sofreram, buscando concordância e complementaridade com seu interlocutor (CARDOSO, 2015). Já os jovens utilizam, como estratégia contra o preconceito, sua capacidade de acomodação e convergência de fala (BORTONI-RICARDO, 2011).

PALAVRAS-CHAVE: Avaliação Linguística; Sociolinguística; Nova Friburgo. 
RESUMEN: Este artículo es parte de la tesis que investigó, en la Sociolingüística, la variedad dialéctica de las comunidades rurales del 30 Distrito de Nova Friburgo, partiendo de la hipótesis de que en ella había una archicomunidad de habla (ECKERT; MCCONNELL-GINET, 2010). Su objetivo es comprender cómo los propios hablantes evalúan su variedad y cómo la ven frente a otra considerada de prestigio (LABOV, 2008; CARDOSO, 2015), teniendo en cuenta que el juicio lingüístico es cargado de valores simbólicos que contribuyen a la valorización o a la estigmatización de un grupo de personas hablantes. Se realizaron 39 entrevistas con residentes, siendo 19 del grupo de edad 1 (entre 35 y 50 años) y 20 del grupo de edad 2 (entre 14 y 18 años); 20 mujeres y 19 hombres. Los resultados demostraron que la juventud domina más de un código oral e intenta accionarlos de acuerdo con el contexto. Esto apunta a dos conclusiones: la generación más nueva, si no domina todas las reglas de la lengua estándar, al menos reconoce el ambiente en que su variedad es aceptada y conoce los mecanismos para adecuar su habla, aunque no logra éxito en todas sus realizaciones; y si hay problemas con la aceptabilidad de esta variedad es porque sufre prejuicio. Así, como probablemente los de más edad fueron los que más quedaron expuestos a la evaluación negativa de habla, ellos reproducen la estigmatización que sufrieron, buscando concordancia y complementariedad con su interlocutor (CARDOSO, 2015). Los jóvenes utilizan, como estrategia contra el prejuicio, su capacidad de acomodación y convergencia de habla (BORTONI-RICARDO, 2011).

PALABRAS CLAVES: Evaluación Lingüística; Sociolingüística; Nova Friburgo.

\section{INTRODUÇÃO}

Este artigo é parte da tese que se dedicou a investigar, no âmbito da Sociolinguística, a variedade dialetal das comunidades rurais do 3을 Distrito de Nova Friburgo. Partiuse, em uma microanálise, da seguinte compreensão: tal 
território se constitui de várias comunidades de prática (ECKERT; McCONNELL, 2010; SEVERO, 2007b), já que nele se encontram inúmeros grupos que se organizam por afinidades e objetivos em comum, como o caso das associações de moradores e agricultores e as capelas e/ ou congregações evangélicas; e que há ali uma rede mais ou menos complexa (BORTONI-RICARDO, 2011), devido à presença desses agrupamentos e das relações de amizade e parentesco estabelecidas entre os moradores. De um ponto de vista macroanalítico da variedade local, entende-se que essa é uma comunidade de fala (LABOV, 2008), uma vez que compartilha vários aspectos identitários da língua. Todavia, não se nega que mesmo em uma determinada variedade há variação e que ela pode ser, muitas vezes, negociada, sendo por isso não homogênea. Diante dessas considerações, infere-se que essa região forma uma arquicomunidade (ECKERT; McCONNELL, 2010), visto que o espaço rural do 3o Distrito, por conta de suas características geográficas, sociais e vernaculares, funciona identitariamente como uma comunidade guarda-chuva (ECKERT; McCONNELL, 2010, p.104), abarcando todas as outras possíveis organizações que nele residem.

Pretendia-se identificar se a variedade falada pelas famílias agricultoras da região orientava-se para o prestígio ou para 
a manutenção da identidade, de acordo com os estudos de Labov (2008) e com os preceitos de comunidades de prática (ECKERT; MCCONNELL-GINET, 2010; SEVERO, 2007b) e de redes sociais (BORTONI-RICARDO, 2011). Para aqueles, o domínio de certas variedades pode garantir inclusão em outras comunidades consideradas como de referência ou constituir a demarcação de certos grupos sociais. Para estes, a língua é determinadora de identificações e relações entre indivíduos, ambas sujeitas a modificações, acomodações e negociações. Todas as abordagens, no entanto, admitem a influência de questões sociais na constituição tanto da variedade como da identidade, o que traz a trabalhos dessa natureza um caráter etnográfico, visto que devem considerar, em sua análise, os modos de fazer e conviver dos grupos estudados.

Diante desses pressupostos, buscou-se, primeiramente, identificar os grupos sociais e as comunidades rurais do território analisado, levantar aspectos linguístico-identitários referentes à fonética e à morfossintaxe, para, então, compreender como os próprios falantes avaliam a sua variedade e como a veem frente a outra considerada de prestígio. É sob esse último objetivo que se concentra a análise apresentada aqui, levando em conta que o julgamento linguístico é carregado de valores simbólicos que podem contribuir para a valorização ou para a estigmatização de um grupo de falantes. 
Assim, além do embasamento teórico sobre a avaliação e identidade linguística, procurou-se, de forma sintética, descrever a comunidade pesquisada e seus informantes e a metodologia empregada para a recolha de dados. Em seguida, fez-se uma exposição dos testes empregados e dos dados sistematizados, buscando sempre compreender o fenômeno avaliativo sob suas variáveis de idade, grau de instrução e sexo. Por fim, para um melhor refinamento da análise e indicações de conclusão, os dados dos dois testes foram confrontados. Vale destacar que se estabeleceu uma grande interação entre os interlocutores da pesquisa, pesquisador-informante, o que contribuiu para que outros fatores observados na convivência fossem acionados na compreensão das atitudes e dos registros vernaculares, demostrando, por isso, a importância de uma investigação etnográfica nas pesquisas sociolinguísticas.

\section{UMA PEQUENA INTRODUÇÃO A RESPEITO DAS ATITUDES, CRENÇAS E AVALIAÇÃO DO FALANTE E DE SUA VARIEDADE}

Segundo Lucchesi, "a avaliação social reforça o valor simbólico das diferenças linguísticas" (LUCCHESI, 2015, p.35), o que implica diretamente o comportamento dos falantes e, por conseguinte, a utilização objetiva e subjetiva da língua. Assim, tem-se o uso que gera avaliação que pode 
acarretar mudança (LUCCHESI, 2015, p.36). A variação, então, não estaria sob influência apenas do contexto, mas também do julgamento do ouvinte que aprovaria ou não a variante (HORA e LOPES, 2015, p.86). Diante disso, para a ciência sociolinguística, considerar as crenças, as ações e a apreciação dos usuários frente a uma determinada variedade e ao seu dialeto é primordial, não só para compreender a variação e sua relação com as questões sociais que a envolvem, como para examinar o processo sincrônico e diacrônico de mudança linguística e a categorização social a partir de questões dialetais (CARDOSO, 2015, p.14). Ademais, segundo Hora e Lopes:

O estudo das atitudes linguísticas é importante para a sociolinguística porque, a partir dele, pode-se prever um determinado comportamento linguístico, como a escolha de uma língua ou variação particular em uma comunidade multilíngue, a lealdade de uma determinada variante, a variante de prestígio ou estigmatizada, dentre outros. (HORA e LOPES, 2015, p.80)

O ajuizamento linguístico, de acordo com Cardoso (2015, p.9), nada mais é do que uma apreciação social, na qual também estão presentes a autorrepresentação e a autoavaliação, que tendem a fazer com que o falante aproxime sua fala daquela considerada modelo (LABOV, 2008, p.161; CARDOSO, 2015, 
p.10), já que a variação adotada é forte indício de identidade de grupo. Ele se baseia na capacidade de identificação e associação das variantes a categorias sociais de valor positivo ou negativo (HORA; LOPES, 2015, p.81; 86). Nesse sentido, o indivíduo nega ou filia-se à imagem à qual pretende ser associado. Cardoso ainda afirma que:

os estudos mais recentes da sociolinguística sugerem que a avaliação que um ouvinte faz da língua de um falante depende, em grande parte, das atitudes linguísticas pré-estabelecidas em relação ao dialeto, à classe social e ao grupo étnico desse falante. (CARDOSO, 2015, p.15)

As atitudes linguísticas podem ser compreendidas, portanto, como o resultado mais concreto das representações simbólicas que são criadas a partir dos fenômenos linguísticos. Assim:

o falante emite um julgamento sobre as variedades linguísticas, e associa a elas diferentes valores, hierarquizandoas: um modo de falar é visto como "desagradável" e "feio", um outro como "cantado" e "lento", e outro, enfim, como "importante" e "conhecido", símbolo de signo de cultura. (CARDOSO, 2015, p.9-10)

Associando a avaliação com a atitude de um sujeito frente a uma determinada variedade se pode depreender como ele próprio se sente em relação a sua identidade linguística. De certa forma, a observação das crenças e do procedimento 
linguístico do falante traz à tona os princípios da Teoria da Acomodação de Giles (1980, Apud BORTONI-RICARDO, 2011) e da hipótese geral de Le Page (1980, Apud BORTONIRICARDO, 2011) para a motivação do comportamento linguístico individual. A primeira defende que, de acordo com a avaliação do falante, pode haver: convergência da sua fala, para que ele consiga atração e apoio do modelo ao qual ele quer se associar linguística e identitariamente; divergência do arquétipo de seus interlocutores como estratégia para a marcação e a manutenção de identidade; e complementaridade de fala, quando reconhece, na relação interlocutória, que sua fala e sua posição social são subordinadas e inferiores a outras, o que remete a uma aceitação da condição subalterna e não o reconhecimento de uma relação de alteridade. Já a segunda coloca que o falante consegue estabelecer regras a fim de se integrar a grupos que linguística e socialmente the parecem mais interessantes, desde que: identifique um modelo; tenha capacidade de acessar o grupo e manipular seu repertório; haja motivação para a dissociação ou para a manutenção de sua identidade; e apresente condições de alterar seu comportamento linguístico (BORTONI-RICARDO, 2011).

Complementando essas abordagens, Bell (1984, Apud HORA e LOPES, 2015) compreende que o resultado da 
acomodação linguística que um falante pode fazer em sua própria variação seria o estilo. A teoria de Audience Design defende que o falante modela suas respostas nos eventos interativos de acordo com sua audiência, podendo redefinir os papéis interlocutórios quando se detecta divergências linguísticas com o(s) destinatário(s). Nesse sentido, a interferência que modificaria o estilo de um falante poderia ser causada pelo tema, pelo ambiente ou, principalmente, pelo interlocutor, de acordo com suas características pessoais e sociais e sua variação (HORA e LOPES, 2015, p.76-77).

A partir dos registros dessas situações que permeiam a avaliação dos falantes, pode-se analisar se a variedade em questão está se aproximando daquela considerada a de prestígio ou a estigmatizada, ou, ainda, se ela se configura como símbolo de manutenção ou rompimento de identidade. Contudo, assim como colocara Labov (2008), havendo motivação, é possível que grande parte dos indivíduos tenha habilidade linguística para atuar em mais de um sistema sociolinguístico e se agregar a um grupo de referência. 0 impulso, implicado por uma atitude avaliativa, tem caráter múltiplo. Ele é empírico, emotivo, afetivo e cognitivo e, por isso, está sob o olhar de outro campo científico: a psicologia social (BORTONI-RICARDO, 2011; CARDOSO, 2015). 
Sobre tal aspecto, Cardoso adota um conceito de atitude de estrutura tridimensional, baseado nos estudos de Rokeach (1974), "Nele os pensamentos e as crenças representam a dimensão cognitiva; os sentimentos e ações, a dimensão afetiva; e as tendências para reagir representam a dimensão conativa." (CARDOSO, 2015, p.17). Essa concepção é teoricamente compreendida como mentalista, tendo como representante Allport, e se difere, portanto, da corrente behaviorista que considera apenas o comportamento afetivo (HORA e LOPES, 2015, p.81). A atitude é vista, pois, como uma reação afetivo-cognitiva-conativa, positiva (valorização) ou negativa (rejeição), a pessoas, objetos, situações, acontecimentos e, aqui, variedades linguísticas. No entanto, ela não é apenas um resultado, mas um processo sociossimbólico, “ou seja, a percepção do objeto e a demonstração ativa de um indivíduo (...) são precedidas e reforçadas por outros procedimentos: o enquadramento do objeto no sistema de crenças e valores do indivíduo e sua eventual reação emotiva a ele." (CARDOSO, 2015, p.18).

Voltando a Lucchesi (2015), é a atitude que leva a uma avaliação dos usos, variedades e variantes da língua e que, dependendo do seu resultado - a aversão ou a aceitação -, pode provocar mudanças. Como essa valoração passa por questões tanto subjetivas quanto sociais, ela pode afetar 
os padrões linguísticos coletivos e interferir nos processos simbólicos de reconhecimento identitário por meio da linguagem. Ou seja, o julgamento de certos padrões pode estabelecê-los como arquétipos aos quais se pretende associação ou como modelos para os quais se deseja uma dissociação. No caso das identidades linguísticas, tanto os padrões como os seus julgamentos podem variar de acordo com o espaço, o lugar, as comunidades e as redes estabelecidas.

Alguns testes podem ser aplicados para que a avaliação do falante frente a uma determinada variação ou variedade possa ser analisada. No caso desta pesquisa, optou-se por recolher dados atitudinais e avaliativos com dois tipos de teste: em ausência de estímulo de fala (CARDOSO, 2015, p.35), quer dizer, a avaliação do falante sobre o falar da comunidade a partir de questões propostas, sem que houvesse, para isso, uma fala específica a ser avaliada; e com áudio modelo (CARDOSO, 2015. p.31), no qual a incitação para o julgamento partiu de duas falas gravadas, a de uma moradora da região rural do 3을 Distrito de Nova Friburgo-RJ e a de uma informante "forasteira", residente nas proximidades do Centro da Cidade, mas que conservava contato com a região pesquisada. Obteve-se aqui a seguinte disposição de informantes: 39 ao todo, sendo 19 representantes da faixa 
etária/geração 1 (entre 35 e 50 anos) e 20 da faixa etária/ geração 2 (entre 14 e 18 anos); distribuídos, quase que igualmente, entre os dois gêneros, 20 mulheres e 19 homens.

Sabia-se que as amostras deveriam representar todo o território rural da localidade que contava, consoante as informações apresentadas pelos moradores, com 7 núcleos comunitários. Esses bairros foram identificados por suas características rurais seguindo os critérios de ruralidade descritos pelos próprios entrevistados, a saber: a necessidade de a maior parte da população local trabalhar em atividades ligadas à agropecuária; a típica disponibilidade da infraestrutura de serviços, principalmente públicos e de comércio, no bairro onde residem; a existência de laços afetivos entre os moradores da localidade; e a manutenção de padrões comportamentais dos habitantes identificáveis por oposição ao centro urbano. No entanto, uma das comunidades indicadas não pode ser acessada e contou-se com os seguintes bairros ou aglomerados rurais (CANDIDO, 2010; COMERFORD, 2005; FRAZAO, 2015; OLIVEIRA, 2011) na pesquisa de campo: Barracão dos Mendes; Salinas, Alto de Salinas e Patrocínio; Santa Cruz e Centenário; Três Picos e Jaborandi; Baixada de Salinas e Campestre; São Lourenço, São Felipe e Fazenda Schuenck. 


\section{AUTOAVALIAÇÃO DA COMUNIDADE: ANÁLISE EM AUSÊNCIA}

No exame em ausência, serviram como estímulo à avaliação dos sujeitos testados perguntas pré-elaboradas e que faziam parte do 5ㅇ Bloco do Roteiro de Entrevista. Essa era a partição de cunho metalinguístico e, por isso, foi deixada para o final do inquérito. No total, foram organizadas, nesse bloco, 10 questões com a intenção de compreender como a comunidade percebia sua própria variedade e como a avaliava sem um áudio modelo. Muitas vezes as perguntas foram propositalmente redundantes para que a avaliação pudesse ser (re)testada e confirmada. Os dados foram computados e analisados com a ajuda do programa GoldVarb para que o cruzamento das informações, quaisquer que fossem, pudesse ser facilitado. Como a variável independente idade, neste caso, foi considerada a mais importante, ela foi utilizada como chave para a distribuição de todos os outros dados. Por meio dela talvez seja possível identificar se há mudanças linguístico-identitárias em progresso, como elas estão sendo avaliadas e que informações simbólicas elas podem veicular (LABOV, 2008, p.326).

Assim, na primeira questão, buscou-se saber se a comunidade reconhecia na sua fala uma variedade linguística diatópica. O resultado obtido foi o seguinte: 


\begin{tabular}{|c|c|c|c|c|c|}
\hline & & Geração 1 & Geração 2 & № & $\%$ \\
\hline $\begin{array}{l}\text { Concordaram com a existência de } \\
\text { uma variação diatópica na região. }\end{array}$ & $\begin{array}{l}\text { № } \\
\%\end{array}$ & $\begin{array}{c}17 \\
45.9\end{array}$ & $\begin{array}{c}20 \\
54.1\end{array}$ & 37 & 94.9 \\
\hline $\begin{array}{l}\text { Não concordaram com a existência } \\
\text { de uma variação diatópica na região. }\end{array}$ & $\begin{array}{l}\text { № } \\
\%\end{array}$ & $\begin{array}{c}1 \\
50\end{array}$ & $\begin{array}{c}1 \\
50\end{array}$ & 2 & 5.1 \\
\hline \multicolumn{2}{|l|}{ Total } & 18 & 21 & 39 & \\
\hline
\end{tabular}

Tabela 1 - Avaliação da existência de variedade diatópica1.

Pela representação do resultado, pode-se perceber que apenas dois entrevistados, um de cada geração, não reconheceram a fala da comunidade como característica. Não houve diferença significativa quando se analisou separadamente as duas gerações, já que cerca de 95\% dos jovens (Geração 2) e 94\% dos pais ou avós (Geração 1) entrevistados afirmaram haver uma variedade linguística na localidade. Em uma verificação final, comprova-se, então, que $94,9 \%$ da amostra pesquisada concordam com a hipótese apresentada nesta pesquisa de que há uma variação diatópica, ou uma variedade dialetal, na zona rural do 3 ㅇ Distrito de Nova Friburgo.

Esse dado foi complementado pela questão 6 do Roteiro de Entrevista que pretendia descobrir que justificativa era encontrada pela comunidade para explicar sua própria variação. Como o tópico era mais aberto, optou-se por

\footnotetext{
1 Resultado referente às perguntas: "Você acha que as pessoas da comunidade falam diferente? Por quê?".
} 
considerá-lo a partir da elucidação dos entrevistados, seguindo as premissas da etnografia. Consequentemente, devido à metodologia empregada, alguns deles elencaram mais de uma possibilidade de explicação para o fenômeno que puderam ser resumidas em, principalmente, dois grandes grupos:

1) Falta de estudo formal ou pouca escolaridade, já que só há uma instituição educacional com oferta de Ensino Médio na região e duas que oferecem o 2o Segmento do Ensino Fundamental. A primeira funciona ali há um pouco mais de 20 anos e também foi a que fundou o 20 Segmento do Ensino Fundamental na localidade. Ou seja, apenas a geração dos mais jovens teve a possibilidade de contato sistemático com estudos um pouco mais elevados. Nesse sentido, segundo relato dos próprios representantes da geração mais velha, a falta de perspectiva em continuar os estudos os desmotivava até mesmo a terminar o 10 Segmento do Ensino Fundamental. 2) Marca regional, transmitida no interior das famílias, de geração em geração, uma vez que a fala identitária pode ser percebida mesmo naqueles que possuem um maior nível de escolaridade. Cabe ressaltar que essa justificativa foi mais frequente entre os jovens, isto é, entre aqueles que têm maior vivência em ambientes formais de estudo, pois todos já estão completando seu Ensino Médio e muitos circulam por 
outros espaços educacionais, como cursos de informática e de aperfeiçoamento profissional, além de pré-vestibulares.

O que também parece ficar claro é a associação entre a falta de estudos e as gerações mais antigas. Foi comum o reconhecimento, pela e na fala dos mais velhos, de uma marca identitária maior e está se justifica, para os entrevistados, pela dificuldade deles em acessar a escola. Para alguns jovens (3) a questão geracional da variação também pode se relacionar à falta de interação dos moradores de mais idade com os centros urbanos, pois a dificuldade de locomoção e transporte era muito maior há algumas décadas do que hoje.

A segunda questão tinha como finalidade entender se a variação diatópica era uniforme em todo o 3음 Distrito ou se havia alguma diferenciação entre as comunidades:

\begin{tabular}{|c|c|c|c|c|c|}
\hline & & Geração 1 & Geração 2 & № & $\%$ \\
\hline $\begin{array}{l}\text { Consideraram a variedade uniforme em } \\
\text { todo o território. }\end{array}$ & $\begin{array}{c}\text { № } \\
\%\end{array}$ & $\begin{array}{c}7 \\
38.9\end{array}$ & $\begin{array}{c}11 \\
61.1\end{array}$ & 18 & 46.2 \\
\hline $\begin{array}{l}\text { Consideraram a variedade característica } \\
\text { de apenas algumas comunidades. }\end{array}$ & $\begin{array}{l}\text { № } \\
\%\end{array}$ & $\begin{array}{c}8 \\
53.3\end{array}$ & $\begin{array}{c}7 \\
46.7\end{array}$ & 15 & 38.5 \\
\hline Não avaliaram. & $\begin{array}{l}\text { № } \\
\%\end{array}$ & $\begin{array}{c}3 \\
50\end{array}$ & $\begin{array}{c}3 \\
50\end{array}$ & 6 & 15.4 \\
\hline Total & & 18 & 21 & 39 & \\
\hline
\end{tabular}

Tabela 2 - Avaliação da uniformidade territorial da variedade2.

2 Resultado referente à pergunta: "Essa fala é igual em todas as comunidades do 3oㅗistrito?". 
Nota-se que para a maioria dos informantes, 46,2\%, há uma homogeneidade na fala de todo o território rural, o que ratifica mais uma vez outra hipótese levantada aqui: a de que há uma arquicomunidade (ECKERT; McCONNELL, 2010), de fala no 3o Distrito de Nova Friburgo. Dentre os sujeitos inquiridos que mencionaram essa resposta, 61,1\% são jovens, demonstrando que para a geração mais nova há uma maior representação identitária local pela fala. Evidenciamse ainda mais os números quando analisados os percentuais totais de cada faixa etária: $52 \%$ dos jovens e $38 \%$ dos mais velhos acreditam em uma regionalidade linguística mais uniforme.

Para aqueles que reconhecem variações dentro do território, 38,5\%, não houve grande diferença de percepção entre as duas gerações. Contudo, se comparados em sua totalidade, 44\% da geração 1 e 33\% da geração 2 percebem irregularidades territoriais na fala. De acordo com eles, as distinções são percebidas, principalmente, na fala dos moradores da comunidade dos Três Picos, que parece ser mais tradicional, guardando traços arcaizantes e aspectos de uma formalidade religiosa católica dispensada, especialmente, no tratamento para com os idosos: 


\begin{tabular}{|c|l|}
\hline INFOR. & FALA \\
\hline 01 & $\begin{array}{l}\text { (...) Purque a referença deles é mais... a educação deles são mais... } \\
\text { intendeu? Os custume de Três Bico não mudô, purque Três Bico, os } \\
\text { mais novo toma bença, beja na mão, têm uma referença de assim } \\
\text { um respeito maió do que, do que, os otros lugá, intendeu? E até a } \\
\text { devoção é maió, nê! Intendeu? Eles são mais devoto, e são a gente } \\
\text { com mais respeito, principalmente com os mais velho, coisa que a } \\
\text { gente tá vendo nas otras comunidades se acabando, o respeito de } \\
\text { tomá a bença, chamá de senhô, intendeu? De bejá na mão, inten- } \\
\text { deu? É: bença, tio! E não INTERROMPÊ os mais velho falando, e Três } \\
\text { Bicos ainda continua exatamente como era de primero a reverença } \\
\text { e até o sutaque, deles é diferente (...) }\end{array}$ \\
\hline
\end{tabular}

\begin{tabular}{|c|l|}
\hline INFOR. & FALA \\
\hline 04 & $\begin{array}{l}\text { Ah eu acho que é! Acho que é só por Três Picu que diferencia um } \\
\text { poco, que eles lá, sei lá, eles falum com mais crença... num sei... }\end{array}$ \\
\hline
\end{tabular}

\begin{tabular}{|c|l|}
\hline INFOR. & FALA \\
\hline 06 - A & $\begin{array}{l}\text { aí tu chega lá nus Três Pico tu vê aquelas pessoa mais antigo falando } \\
\text { diferente, tu... tu nota a diferença, intendeu? }\end{array}$ \\
\hline
\end{tabular}

Além disso, alguns entrevistados dizem reconhecer e diferenciar até mesmo algumas famílias por seu modo de falar. As distinções apresentadas, no entanto, não parecem ser dialetais, mas sim no temperamento e no comportamento dos indivíduos que tendem a ser manifestadas no tom de voz e nas formas de tratamento interpessoais.

Por fim, $15,4 \%$ dos entrevistados ou não souberam avaliar essa questão ou simplesmente não responderam. Tal fato, como será apresentado na disposição de outros dados, repetiu-se inúmeras vezes e com porcentagens mais significativas, indicando, talvez, uma dificuldade dos sujeitos 
testados, em sua maioria os mais velhos, em formar juízos de valor a partir de uma apreciação da fala local. O fenômeno pode representar duas premissas: ou a comunidade se nega a construir pré-conceitos sociais simbolicamente baseados na fala; ou a abstenção é uma autodefesa, já que com o possível julgamento estar-se-ia diante, também, de uma autoavaliação.

A terceira questão se destinava a identificar se a identidade linguística era de fato perceptível. Para tanto, perguntouse se somente pela fala o entrevistado reconheceria um morador da região. As respostas obtidas foram:

\begin{tabular}{|c|c|c|c|c|c|}
\hline & & Geração 1 & Geração 2 & № & $\%$ \\
\hline $\begin{array}{l}\text { Reconheceriam um morador da re- } \\
\text { gião por sua fala. }\end{array}$ & $\begin{array}{l}\text { № } \\
\%\end{array}$ & $\begin{array}{c}15 \\
45.5\end{array}$ & $\begin{array}{c}18 \\
54.5\end{array}$ & 33 & 84.6 \\
\hline Não avaliaram a questão. & $\begin{array}{l}\text { № } \\
\%\end{array}$ & $\begin{array}{c}3 \\
75\end{array}$ & $\begin{array}{c}1 \\
25\end{array}$ & 4 & 10.3 \\
\hline $\begin{array}{l}\text { Não reconheceriam um morador da } \\
\text { região por sua fala. }\end{array}$ & $\begin{array}{l}\text { № } \\
\%\end{array}$ & $\begin{array}{l}0 \\
0\end{array}$ & $\begin{array}{c}2 \\
100\end{array}$ & 2 & 5.1 \\
\hline Total & & 18 & 21 & 39 & \\
\hline
\end{tabular}

Tabela 3 - Avaliação da possibilidade de reconhecer um morador apenas por sua variedade3.

3 Resultado referente à pergunta: "Você reconheceria uma pessoa de sua região só pelo modo de falar?" 


\begin{tabular}{|c|c|c|c|c|c|c|c|}
\hline & & \multicolumn{2}{|c|}{ Mulheres } & \multicolumn{2}{|c|}{ Homens } & \multirow[t]{2}{*}{ № } & \multirow[t]{2}{*}{$\%$} \\
\hline & & № & $\%$ & № & $\%$ & & \\
\hline \multirow{2}{*}{$\begin{array}{l}\text { Reconheceriam um morador } \\
\text { da região por sua fala. }\end{array}$} & Geração 1 & 8 & 47 & 7 & 44 & 15 & 45 \\
\hline & Geração 2 & 9 & 53 & 9 & 56 & 18 & 55 \\
\hline \multicolumn{2}{|l|}{ Total } & \multicolumn{2}{|c|}{17} & \multicolumn{2}{|c|}{16} & 33 & \\
\hline \multirow{2}{*}{$\begin{array}{l}\text { Não reconheceriam um mora- } \\
\text { dor da região por sua fala. }\end{array}$} & Geração 1 & 0 & 0 & 0 & 0 & 0 & 0 \\
\hline & Geração 2 & 1 & 100 & 1 & 100 & 2 & 100 \\
\hline \multicolumn{2}{|l|}{ Total } & \multicolumn{2}{|c|}{1} & \multicolumn{2}{|c|}{1} & 2 & \\
\hline \multirow[t]{2}{*}{ Não avaliaram a questão. } & Geração 1 & 2 & 100 & 1 & 50 & 3 & 75 \\
\hline & Geração 2 & 0 & 0 & 1 & 50 & 1 & 25 \\
\hline \multicolumn{2}{|l|}{ Total } & \multicolumn{2}{|c|}{2} & \multicolumn{2}{|c|}{2} & 4 & \\
\hline
\end{tabular}

Tabela 4 - Avaliação, por sexo, da possibilidade de reconhecer um morador apenas por sua variedade.

Praticamente $85 \%$ dos entrevistados afirmaram ser possível reconhecer um morador da região apenas pela fala. Desses, a maioria, 55\%, são jovens que mantêm uma maior rede de relações fora da região, demonstrando, então, que o convívio com outros ambientes linguísticos pode favorecer a percepção das diferentes variações. 0 resultado aqui ratifica o que foi identificado na primeira questão, uma vez que os jovens distinguem a variação diatópica daquela região em maior número do que os seus familiares mais velhos. Apenas $5 \%$ dos informantes alegaram ser essa tarefa impossível. Em números totais, $86 \%$ dos jovens e $83 \%$ dos mais velhos reconheceriam, apenas pela fala, um nativo da região. Quando analisados por gênero e não por faixa etária, os dados não 
demonstram diferença entre homens e mulheres, já que 95\% delas e deles reconheceriam um morador da região por seu dialeto.

Na quarta questão, o propósito era diagnosticar se a identidade linguística da comunidade se estendia ao próprio entrevistado, ou seja, se ele se via como pertencente ao grupo linguístico da sua comunidade. Chegou-se, assim, ao seguinte dado:

\begin{tabular}{|l|c|c|c|c|c|}
\hline \multicolumn{2}{|l|}{} & Geração 1 & Geração 2 & № & $\%$ \\
\hline Reconheceram falar a variedade local. & № & 15 & 14 & 29 & 74.4 \\
& $\%$ & 51.7 & 48.3 & & \\
\hline Não reconheceram falar a variedade local. & № & 2 & 7 & 9 & 23.1 \\
& $\%$ & 22.2 & 77.8 & & \\
\hline Não avaliaram. & № & 1 & 0 & 1 & 2.6 \\
& $\%$ & 100 & 0 & & \\
\hline Total & & 18 & 21 & 39 & \\
\hline
\end{tabular}

Tabela 5 - Avaliação da própria fala como pertencente à variedade local4.

Nesse quesito a proporção se inverteu, pois, a geração de mais idade se compreende, em maior quantidade, 51,7\%, no grupo de usuários da variedade aqui estudada. O evento é ainda mais perceptível no grupo da negação, na qual $77,8 \%$ são jovens que entendem não falar mais como a comunidade, ou seja, eles veem que a sua variedade está se modificando. Em percentuais gerais por geração, têm-se 83\% dos mais

4 Resultado referente à pergunta: "Você fala como as pessoas de sua comunidade?" 
velhos e $67 \%$ dos mais jovens se identificando como usuários dessa variedade. Novamente aqui, as redes de relação parecem exercer um papel fundamental, assim como o acesso à instrução formal, já que eles indiciam uma maior consciência na adaptação e na acomodação linguística. Contudo, cabem outras reflexões para que o dado seja validado, como será feito mais adiante.

Tal resultado apresenta grande distinção se a variável sexo é levada em consideração: $85 \%$ das mulheres e $63 \%$ dos homens reconhecem que falam como a comunidade, assim como $15 \%$ delas e $32 \%$ deles acreditam não falar como a comunidade. Os meninos aqui representam um peso maior, pois dos 6 informantes do sexo masculino que acreditam falar diferente da comunidade, 5 são jovens.

A quinta questão buscava estabelecer se o falante tinha vergonha ou orgulho da sua fala. Assim, obteve-se:

\begin{tabular}{|l|c|c|c|c|c|}
\hline \multicolumn{2}{|l|}{} & Geração 1 & Geração 2 & № & $\%$ \\
\hline Sentem orgulho. & № & 10 & 16 & 26 & 66.7 \\
& $\%$ & 38.5 & 61.5 & & \\
\hline Têm orgulho, mas já sentiram vergonha. & № & 4 & 1 & 5 & 12.8 \\
& $\%$ & 80 & 20 & & \\
\hline Não avaliaram. & № & 2 & 2 & 4 & 10.3 \\
& $\%$ & 50 & 50 & & \\
\hline
\end{tabular}




\begin{tabular}{|l|c|c|c|c|c|}
\hline Não têm orgulho nem vergonha. & № & 1 & 2 & 3 & 7.7 \\
& $\%$ & 33.3 & 66.7 & & \\
\hline Sentem vergonha. & № & 1 & 0 & 1 & 2.6 \\
& $\%$ & 100 & 0 & & \\
\hline \multicolumn{2}{|c|}{ Total } & 18 & 21 & 39 & \\
\hline
\end{tabular}

Tabela 6 - Atitude do falante frente a sua variedade5.

Novamente houve uma inversão. A faixa etária 2 mesmo majoritariamente não reconhecendo sua fala como representante daquele território ou, simplesmente, compreendendo que ela está em processo de mudança, apresenta mais orgulho da variedade local do que a faixa etária 1. Embora a maioria dos entrevistados $(66,7 \%)$ sinta mais orgulho do que vergonha, os jovens representam $61,5 \%$ desse grupo. Nenhum deles afirmou simplesmente se envergonhar de sua fala, mas isso não significa que já não se tenham sentido constrangidos em relação a ela, assim como alguns adultos. 12,8\%, 4 adultos e 1 jovem, dos sujeitos testados afirmaram ter orgulho de sua fala e junto a isso depuseram ter passado por situações de interlocução que os constrangeram. Além deles, 7,7\% (1 adulto e 2 jovens), relataram não sentir nem orgulho, nem vergonha.

O fenômeno aqui observado parece indicar mais duas possíveis análises: ou os jovens estão desenvolvendo a habilidade de adequar sua fala aos ambientes diversos em que circulam,

5 Resultados referentes às perguntas: "Você tem orgulho do seu modo de falar? Por quê?" e "Já sentiu vergonha do seu modo de falar? Por quê?" 
protegendo-se assim do preconceito vivido por seus pais; ou eles reconhecem na variedade da comunidade a representação simbólica de sua história, de sua identidade, de sua família e, por isso, sentem orgulho, mesmo compreendendo que sua fala já se diferencia daquela vinculada aos "mais antigos". Em ambos os casos, estar-se-ia diante de uma grande consciência linguística da geração mais jovem que tanto a blinda do preconceito linguístico, quanto forja e preserva a sua identidade. Nas duas possibilidades, comprovar-se-ia a proposta de Le Page (1980, Apud BORTONI-RICARDO, 2011), pois os jovens conseguem, desse modo, estabelecer regras linguísticas para se integrar a grupos que socialmente lhes interessam: identificando um modelo; apresentando capacidade de acessá-lo e manipular seu repertório; e, consequentemente, alterando seu comportamento linguístico ao contexto interlocutório, sem com isso, deixar de reconhecer sua própria identidade linguística original.

Quando o gênero é cruzado com a informação anterior, notase que as mulheres têm proporcionalmente menos orgulho do que os homens. No grupo feminino, 50\% das informantes afirmaram se orgulhar de sua fala, enquanto no grupo masculino cerca de $84 \%$ dos entrevistados relataram o mesmo. Contudo, mesmo divididos por sexo, os jovens, principalmente os meninos, continuam a representar um maior quantitativo daqueles que têm orgulho da fala, como pode ser observado no cruzamento de dados abaixo: 


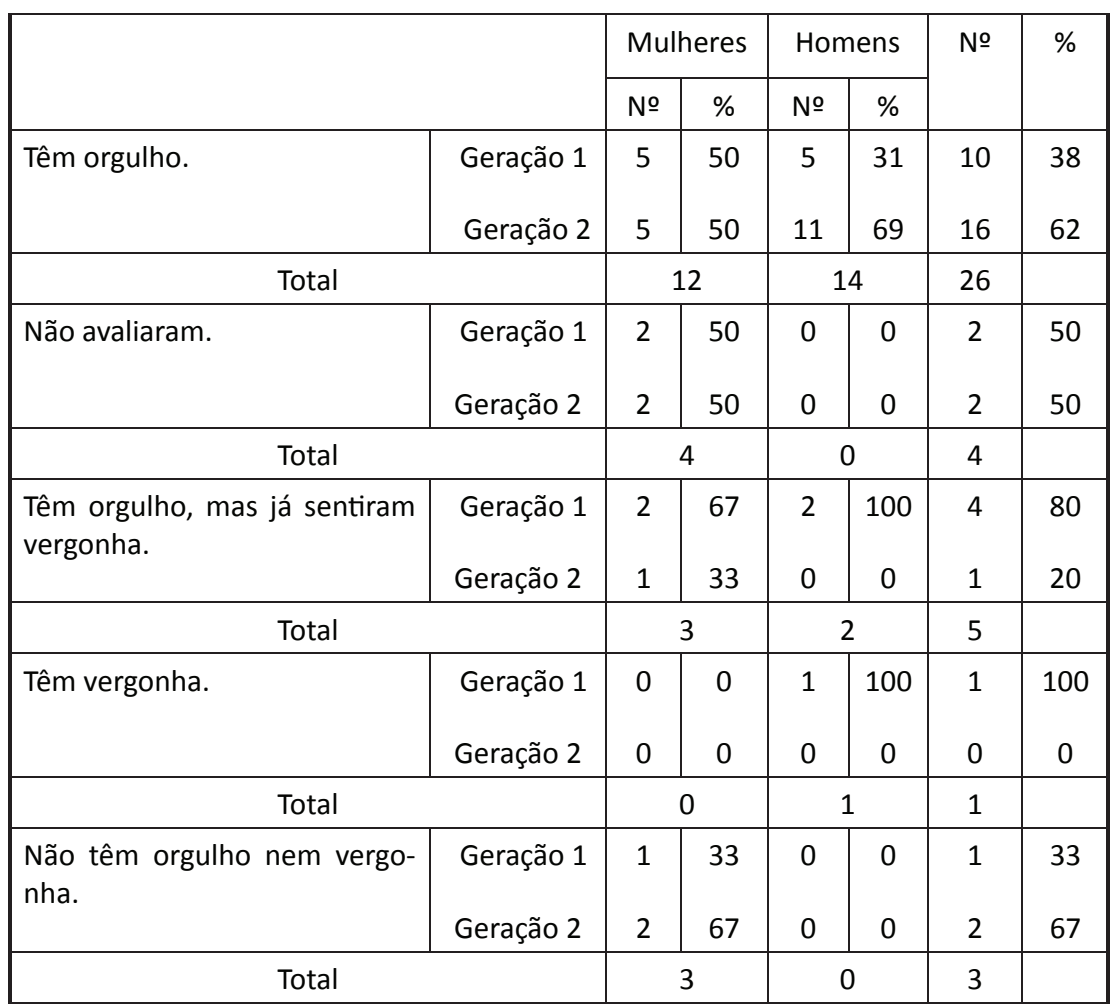

Tabela 7 - Atitude do falante, por sexo, frente a sua variedade.

Todavia, é importante destacar que os meninos que informaram em maior número ter orgulho de sua fala, na questão anterior, reconheceram, em grande parte, falar de forma distinta da comunidade ou estar em processo de mudança. Reiterando, a capacidade de manipular diferentes códigos de linguagem sugere que os jovens, inclusive, tenham condição para que se orgulhem de sua comunidade linguística e coloquem em prática, quando Ihes convém, sua variação. 
Esta estaria associada, de acordo com Bell e Eckert, a uma ação estilística que contribui para a construção da múltipla identidade e para um significado social. Para Bell, "a variação não é somente um reflexo das categorias sociais, mas tem uma relação direta com o uso, com a performance do falante (...) e os estilos são atos de afiliação do falante a uma determinada comunidade de prática." (HORA e LOPES, 2015, p.78). De toda forma, o estigma parece se manter, já que quem se reconhece como usuário dessa variante, com menor habilidade para se adaptar aos diferentes contextos, demonstra menos orgulho, sobretudo, as mulheres mais velhas.

Na sétima questão, o objetivo era depreender de forma mais objetiva a avaliação em relação à fala da comunidade, utilizando tópicos valorativos comuns em trabalhos acadêmicos desse tipo (CARDOSO, 2015, p.9): os informantes deveriam avaliar a fala local como feia ou bonita; agradável ou desagradável. Não se quis medir em números as atitudes, mas aproveitar "seu potencial de polarização entre duas opções" (CARDOSO, 2015, p.36), embora alguns informantes tenham se abstido de tal avaliação, como já fora colocado. Optou-se, nesse tópico, por uma investigação do afetivo. Assim, “O par 'bonito - feio' está ligado principalmente ao domínio do estético, ou seja, do 'gosto' e, por isso mesmo é o mais subjetivo (CARDOSO, 2015, p.38); o par 'agradável - desagradável' faz parte do domínio do hedônico, ou seja, do sensível" (CARDOSO, 2015, p.36). 
Em relação à primeira caracterização, verificou-se que:

\begin{tabular}{|l|c|c|c|c|c|}
\hline \multicolumn{2}{|c|}{} & Geração 1 & Geração 2 & № & $\%$ \\
\hline Consideraram a variedade local bonita. & № & 4 & 13 & 17 & 43.5 \\
& $\%$ & 23.5 & 76.5 & & \\
\hline Não avaliaram. & № & 8 & 7 & 15 & 38.5 \\
& $\%$ & 53.3 & 46.7 & & \\
\hline Consideraram a variedade local feia. & № & 6 & 1 & 7 & 17.9 \\
& $\%$ & 85.7 & 14.3 & & \\
\hline \multicolumn{2}{|c|}{ Total } & 18 & 21 & 39 & \\
\hline
\end{tabular}

Tabela 8 - Avaliação estética da variedade local6.

43,6\% dos entrevistados (a maioria) avaliam a fala da comunidade como bonita, porém o percentual de jovens que têm essa percepção é mais de três vezes maior do que a porcentagem dos mais velhos. Quando a adjetivação é a de carga negativa, tal evidência fica ainda mais clara, já que o número de pais e avós que avaliam sua fala como feia é seis vezes maior do que o de jovens. Fato interessante é que 38,5\% dos informantes declararam não ser possível avaliar uma fala sob esse aspecto, demonstrando que para grande parte deles, $\mathrm{e}$ aí não há diferença significativa entre as duas gerações, parece haver uma negação de qualquer pré-juízo de valor social pela fala, ou, novamente a abstenção da possibilidade de ter que se autoavaliar por consequência. Caso parecido foi vivenciado por Cardoso (2015) que afirmou, a partir dos resultados de sua

6 Resultado referente à pergunta: "Você considera esse modo de falar: ( )feio ou ( )bonito?" 
pesquisa, que o aracajuano "não aceita definir superioridade aplicada a certos elementos da linguagem que implicam em um juízo de valor." (CARDOSO, 2015, p.42)

Já em relação à apreciação por gênero, obteve-se um resultado interessante:

\begin{tabular}{|c|c|c|c|c|c|c|c|}
\hline & & \multicolumn{2}{|c|}{ Mulheres } & \multicolumn{2}{|c|}{ Homens } & \multirow[t]{2}{*}{ № } & \multirow[t]{2}{*}{$\%$} \\
\hline & & № & $\%$ & № & $\%$ & & \\
\hline \multirow[t]{2}{*}{ Consideraram a fala bonita. } & Geração 1 & 1 & 17 & 3 & 27 & 4 & 24 \\
\hline & Geração 2 & 5 & 83 & 8 & 73 & 13 & 76 \\
\hline \multicolumn{2}{|l|}{ Total } & \multicolumn{2}{|c|}{6} & \multicolumn{2}{|c|}{11} & 17 & \\
\hline \multirow[t]{2}{*}{ Não avaliaram. } & Geração 1 & 5 & 56 & 3 & 50 & 8 & 53 \\
\hline & Geração 2 & 4 & 44 & 3 & 50 & 17 & 47 \\
\hline \multicolumn{2}{|l|}{ Total } & \multicolumn{2}{|c|}{9} & \multicolumn{2}{|c|}{6} & 15 & \\
\hline \multirow[t]{2}{*}{ Consideraram a fala feia. } & Geração 1 & 4 & 80 & 2 & 100 & 6 & 86 \\
\hline & Geração 2 & 1 & 20 & 0 & 0 & 1 & 14 \\
\hline \multicolumn{2}{|l|}{ Total } & \multicolumn{2}{|c|}{5} & \multicolumn{2}{|c|}{2} & 7 & \\
\hline
\end{tabular}

Tabela 9 - Avaliação estética da variedade local, por sexo.

Para $25 \%$ dos informantes do sexo feminino e cerca 10 $\%$ do sexo masculino a fala da região é feia. Já $30 \%$ das mulheres e $58 \%$ dos homens a percebem como bonita. $45 \%$ delas e $32 \%$ deles não avaliaram a fala por esse aspecto. De tais resultados, pode-se chegar à conclusão de que os homens tendem a avaliar a variedade em questão de forma mais positiva, ao passo que as mulheres de modo mais negativo, como também percebido por Cardoso em seus 
testes em ausência no estado de Aracaju (CARDOSO, 2015, p.39; 43). No entanto, se analisados gênero e faixa etária em conjunto, percebe-se que o julgamento estigmatizado recai quase sempre sobre a geração 1. Nota-se que das 5 mulheres e dos 2 homens que avaliaram a fala como feia, 4 são mães e os 2 são pais; dos que consideraram bonita, 6 mulheres e 11 homens, 5 são filhas e 8 filhos. Ratifica-se, portanto, que a juventude tende a não ajuizar pejorativamente a fala local, do mesmo modo como ocorreu também na avaliação de Cardoso (2015, p.50).

De modo análogo pode ser compreendido a segunda caracterização:

\begin{tabular}{|l|c|c|c|c|c|}
\hline \multicolumn{2}{|l|}{} & Geração 1 & Geração 2 & № & $\%$ \\
\hline Consideraram a variedade agradável. & № & 4 & 14 & 18 & 46.2 \\
& $\%$ & 22.2 & 77.8 & & \\
\hline Não avaliaram. & № & 12 & 5 & 17 & 43.6 \\
& $\%$ & 70.6 & 29.4 & & \\
\hline Consideraram a variedade desagradável. & № & 2 & 2 & 4 & 10.3 \\
& $\%$ & 50 & 50 & & \\
\hline \multicolumn{2}{|c|}{ Total } & 18 & 21 & 39 & \\
\hline
\end{tabular}

Tabela 10 - Avaliação hedônica da variedade local7.

7 Resultado referente à pergunta: "Você considera esse modo de falar: ( )agradável ou ( ) desagradável?". 


\begin{tabular}{|c|c|c|c|c|c|c|c|}
\hline & & \multicolumn{2}{|c|}{ Mulheres } & \multicolumn{2}{|c|}{ Homens } & \multirow[t]{2}{*}{ № } & \multirow[t]{2}{*}{$\%$} \\
\hline & & № & $\%$ & № & $\%$ & & \\
\hline \multirow[t]{2}{*}{ Consideraram a fala agradável. } & Geração 1 & 2 & 29 & 2 & 18 & 4 & 22 \\
\hline & Geração 2 & 5 & 71 & 9 & 82 & 14 & 78 \\
\hline \multicolumn{2}{|l|}{ Total } & \multicolumn{2}{|c|}{7} & \multicolumn{2}{|c|}{11} & 18 & \\
\hline \multirow[t]{2}{*}{ Não avaliaram. } & Geração 1 & 6 & 67 & 6 & 75 & 12 & 71 \\
\hline & Geração 2 & 3 & 33 & 2 & 25 & 5 & 29 \\
\hline \multicolumn{2}{|l|}{ Total } & \multicolumn{2}{|c|}{9} & \multicolumn{2}{|c|}{8} & 17 & \\
\hline \multirow[t]{2}{*}{ Consideraram a fala desagradável. } & Geração 1 & 2 & 50 & 0 & 0 & 2 & 50 \\
\hline & Geração 2 & 2 & 50 & 0 & 0 & 2 & 50 \\
\hline \multicolumn{2}{|l|}{ Total } & \multicolumn{2}{|c|}{4} & \multicolumn{2}{|c|}{0} & 4 & \\
\hline
\end{tabular}

Tabela 11 - Avaliação hedônica da variedade local, por sexo.

O número de jovens que considera a fala local como agradável é 3,5 vezes maior que a quantidade de pais e avós. Já aqueles que não consideram a fala passível desse tipo de julgamento representam 2,5 vezes o número de pessoas mais velhas. Há aqui, então, uma inversão, quase que perfeita, no percentual entre as gerações. A ideia de que a não avaliação possa representar uma omissão da valoração negativa, inclusive de sua própria fala, e não simplesmente a inexistência de preconceito linguístico, caminha, então, para uma comprovação, o que parece mais certo quando comparados os dois últimos critérios de avaliação. É possível que já haja uma sinalização para compreender como estigmatizada pelos próprios usuários a variedade analisada, pelo menos para a geração mais velha. Tal conclusão pode ser melhor elucidada com o cruzamento dos próximos dados. 
Na oitava questão, desejava-se investigar a consciência linguística daqueles falantes procurando saber se eles já haviam precisado mudar o seu modo de falar ou se falavam de modo igual em todas as situações:

\begin{tabular}{|l|c|c|c|c|c|}
\hline \multicolumn{2}{|l|}{} & Geração 1 & Geração 2 & № & $\%$ \\
\hline Já precisaram mudar o modo de falar. & № & 8 & 17 & 25 & 64.1 \\
& $\%$ & 32 & 68 & & \\
\hline Nunca precisaram mudar o modo de falar. & № & 8 & 4 & 12 & 30.8 \\
& $\%$ & 66.7 & 33.3 & & \\
\hline Não avaliaram. & № & 2 & 0 & 2 & 5.1 \\
& $\%$ & 100 & 0 & & \\
\hline \multicolumn{2}{|c|}{ Total } & 18 & 21 & 39 & \\
\hline
\end{tabular}

Tabela 12 - Avaliação da necessidade de adequação da própria variedade ao contexto8.

Para a maioria dos entrevistados, 64,1\%, principalmente para os jovens, já houve a necessidade de mudança e/ou adequação de fala. Analisando o percentual geral, percebe-se que $81 \%$ dos pertencentes à geração 2 já tiveram que modificar seu modo de falar, enquanto $44 \%$ da geração 1 passaram por situação semelhante. Nesse caso, o sexo não apresentou uma mudança expressiva (por isso não representada na tabela), posto que $60 \%$ das mulheres e $68 \%$ dos homens já precisaram modificar a sua fala. Obviamente aqui o percentual de jovens por gênero também é maior, especialmente os meninos, que afirmaram, em sua maioria, também estar falando 8 Resultado referente às perguntas: "Em algumas situações, você precisou mudar seu modo de falar? Por quê? Você fala igual em todas as situações?" 
diferente de sua comunidade. Os motivos apresentados para a necessidade de mudança podem ser exemplificados pelas falas:

\begin{tabular}{|c|l|}
\hline INFOR. & FALA \\
\hline 20 & $\begin{array}{l}\text { Assim, não é... acho que quando você tá no meio de uma outra co- } \\
\text { munidade, de outras pessoas com modos diferentes, acho que você } \\
\text { precisa, não é que você precisa necessariamente se adaptar, mas } \\
\text { você parece que você tem a necessidade de se adaptar porque se } \\
\text { você falá alguma coisa errada as pessoas vão te (), ou zoar de você. } \\
\text { Então acho que assim, acaba sendo uma necessidade também. De } \\
\text { falar de uma forma correta, de uma forma mais formal dependendo } \\
\text { do lugar onde você esteja. }\end{array}$ \\
\hline
\end{tabular}

\begin{tabular}{|c|l|}
\hline INFOR. & FALA \\
\hline 21 & $\begin{array}{l}\text { Algumas palavras não vô podê falar, assim alguma gíria assim, que } \\
\text { só eu tô acostumada, e quem tá convivendo comigo, porque aí vai } \\
\text { tê outras pessoas e se a pessoa não conhece a palavra não sabe o } \\
\text { que é isso. }\end{array}$ \\
\hline
\end{tabular}

\begin{tabular}{|c|l|}
\hline INFOR. & FALA \\
\hline 24 & Ah, na aula de português tem que prestá, né, ai tem que mudá. \\
\hline
\end{tabular}

\begin{tabular}{|c|l|}
\hline INFOR. & FALA \\
\hline 25 & $\begin{array}{l}\text { Sim, porque às vezes a gente fala uma palavra, xô vê um exemplo, a } \\
\text { gente às vezes tira alguma letra ou põe outras, intão isso não é legal, } \\
\text { intão na hora de apresentá um trabalho tem que tá tudo perfeito. }\end{array}$ \\
\hline
\end{tabular}

\begin{tabular}{|c|l|}
\hline INFOR. & FALA \\
\hline 31 & $\begin{array}{l}\text { Tipo assim quando a gente teve nu(-) acho que no Fundamental } \\
\text { que a gente teve que i lá pro Centro fazê uma apresentação a gen- } \\
\text { te num pudia falá tão errado que nem a gente falava aqui. }\end{array}$ \\
\hline
\end{tabular}

O elenco de justificativas comprova, pois, as possibilidades já aventadas e embasadas em Le Page (1980, Apud BORTONI- 
RICARDO, 2011), Giles (1980, apud BORTONI-RICARDO, 2011) e Bell (1984, Apud HORA e LOPES, 2015): a habilidade de avaliar a situação comunicativa e adaptar sua linguagem, garantindo convergência de fala, é muito presente entre os jovens. Isso faz com que eles se preservem do preconceito, mas se mantenham orgulhosos de sua comunidade diatópica original, até mesmo como forma de resistência e valorização de sua história.

Por fim, buscou-se saber se de modo consciente os entrevistados gostavam de seu falar e se o mudariam, definitivamente, se pudessem fazê-lo:

\begin{tabular}{|c|c|c|c|c|c|}
\hline & & Geração 1 & Geração 2 & № & $\%$ \\
\hline Gostam de sua própria fala. & $\begin{array}{l}\text { № } \\
\%\end{array}$ & $\begin{array}{c}9 \\
33.3\end{array}$ & $\begin{array}{c}18 \\
66.7\end{array}$ & 27 & 69.2 \\
\hline Não avaliaram. & $\begin{array}{l}\text { № } \\
\%\end{array}$ & $\begin{array}{c}6 \\
75\end{array}$ & $\begin{array}{c}2 \\
25\end{array}$ & 8 & 20.5 \\
\hline Não gostam de sua própria fala. & $\begin{array}{l}\text { № } \\
\%\end{array}$ & $\begin{array}{c}3 \\
75\end{array}$ & $\begin{array}{c}1 \\
25\end{array}$ & 4 & 10.3 \\
\hline Total & & 18 & 21 & 39 & \\
\hline
\end{tabular}

Tabela 13 - Autoavalição estética9.

Outra vez, tem-se uma maior valorização da fala local por parte dos jovens. Embora 69,2\% dos informantes tenham declarado gostar de sua variedade, e aí se incluem também a maioria de homens (68\%) e mulheres (70\%),

9 Resultado referente à pergunta: "Você gosta do seu modo de falar?" 
apenas $1 / 3$ deles representa a geração mais velha. Dos que assumiram não gostar de sua fala (10,3\%), 75\% são pais e avós e daqueles que não conseguiram avaliar esse aspecto $(20,5 \%)$, tem-se o mesmo percentual. Os números desse quesito corroboram o julgamento realizado nas questões 5 e 7. Os jovens estigmatizam menos a sua própria fala e, por conseguinte, a variação da região. Eles têm mais orgulho, sentem menos vergonha, acham sua fala bonita e agradável e, portanto, gostam dela. Essa não é uma avaliação apenas contemplativa, mas sim linguisticamente consciente, pois eles também são os que, em sua maioria, reconhecem a fala local como identitária e, por isso, mais perceptível em outros ambientes.

A consciência linguística e a adaptação às comunidades de prática das quais participa parecem ficar mais claras quando esses resultados são analisados à luz da questão 8. A maioria dos que precisaram adequar ou modificar a sua fala pertence à geração 2 e essa adequação e/ou modificação foram motivadas pelo nível de formalidade do ambiente interativo que resultou em uma necessidade de maior correção da fala. Isso demonstra, se não um melhor domínio linguístico, o reconhecimento das modalidades e dos níveis de linguagem e a intenção de acioná-los em suas interlocuções. O automonitoramento dos jovens, provenientes de seu estilo 
(LABOV, 2008), para garantia de maior formalidade, traria, segundo Eckert e McConnell-Ginet (2010), atenção para categorias de prestígio na fala e a proteção contra o estigma (HORA e LOPES, 2015, p.76). Os próximos dados esclarecem ainda mais o evento narrado:

\begin{tabular}{|l|c|c|c|c|c|}
\hline \multicolumn{2}{|l|}{} & Geração 1 & Geração 2 & № & $\%$ \\
\hline Não mudariam o modo de falar. & № & 5 & 16 & 21 & 53.8 \\
& $\%$ & 23.8 & 76.2 & & \\
\hline Não avaliaram. & № & 9 & 3 & 12 & 30.8 \\
& $\%$ & 75 & 25 & & \\
\hline Mudariam o modo de falar. & № & 4 & 2 & 6 & 15.4 \\
& $\%$ & 66.7 & 33.3 & & \\
\hline \multicolumn{2}{|c|}{ Total } & 18 & 21 & 39 & \\
\hline
\end{tabular}

Tabela 14 - Desejo de mudança da variedade a partir da autoavaliação estética10.

53,8\% dos entrevistados não substituiriam, definitivamente, seu modo de falar por outro, não havendo distinção expressiva entre homens e mulheres. Destes $76,2 \%$ são jovens, principalmente meninos, que já reconhecem mudança na sua fala. Por outro lado, $15,4 \%$ dos informantes, se pudessem, abandonariam sua variedade, sendo, apenas $1 / 3$ deles os da geração 2. Ou seja, os mesmos jovens que alegaram já ter adequado sua linguagem devido ao contexto interlocutório e que compreendem que sua fala está em processo de mudança são os mesmos que não abdicariam da utilização de sua variação diatópica.

10 Resultado referente às perguntas: "Você gosta do seu modo de falar? Mudaria se pudesse?" 
Diante de tais dados, pode-se concluir que a valorização e o reconhecimento linguístico-identitário para os jovens se apresentam como uma opção e não como uma imposição. A maioria deles se compreende como pertencente a um grupo linguisticamente diferenciado, assim como os mais velhos. Entretanto, a possibilidade de adaptação aos ambientes interativos é muito maior para aqueles do que para estes. A habilidade de acomodação linguística, que parece ser fruto direto da escolarização e das diferentes experiências comunicativas dos estudantes, se por um lado evidencia as variações linguísticas e a influência externa na língua local, por outro impede que tais falantes se exponham ao preconceito linguístico pelos quais passaram as gerações mais antigas.

Talvez o próprio preconceito sofrido pelos mais velhos e a falta de condições para o prosseguimento dos estudos tenham contribuído para que essa geração veja a sua fala como estigmatizada. Apresentar-se-ia aqui uma articulação de diversos fatores contribuindo para o enraizamento do preconceito linguístico: a falta de habilidade e conhecimento formal para adaptar a linguagem às variadas situações comunicativas levaria a visibilidade social de outro fator que deveria permanecer velado, a baixa escolaridade; esta, por sua vez, associa-se, com fecundidade, à imagem 
de uma zona rural retrógrada e socialmente atrasada e, consequentemente, a um estereótipo de homem do campo como cidadão ingênuo e tolo ou bronco e ignorante. Assim, aquilo que motivaria a vergonha não seria apenas uma questão diatópica da fala, mas também diastrática, ou seja, aquela variação desnudaria as condições de instrução formal às quais os agricultores foram submetidos. A fala, nesse caso, indicaria a identidade, nomeada por eles como "roceiro", que simbolicamente ainda está vinculada a um estigma.

\section{AUTOAVALIAÇÃO DA COMUNIDADE: ANÁLISE COM ÁUDIO MODELO}

A análise com áudio modelo também compunha a partição metalinguística do Roteiro de Entrevista e concluía, portanto, o inquérito investigativo. Os áudios usados como estímulo duravam por volta de 30 segundos e consistiam na narração da infância de duas mulheres, com aproximadamente a mesma idade. O que se pretendia era observar as atitudes dos informantes na presença da fala do outro. A avaliação se deteve a aspectos sociais e estéticos na tentativa de detectar indícios de estigma e reconhecimento identitário.

A autoavaliação em ausência indicou algumas conclusões das atitudes dos falantes em relação ao conhecimento geral que possuíam de sua própria fala a partir da proposição 
de alguns questionamentos. Contudo, "as atitudes que os indivíduos têm longe do objeto (em nosso caso a fala) podem ser iguais ou diferir substancialmente das que têm frente a ele" (CARDOSO, 2015, p.60), sendo, por isso, importante analisá-las sob as duas distintas condições de recolha de dados. Além disso, "quando um indivíduo escuta uma determinada variedade linguística, isto evoca atitudes, preconceitos ou estereótipos relevantes sobre o falante e sobre a comunidade de fala a que ele pertence." (HORA e LOPES, 2015, p.82).

Diante de tal proposta, buscou-se, então, primeiramente saber se para os informantes as falas-estímulo comparadas eram bonitas ou feias. No geral, $59 \%$ dos entrevistados se negaram a fazer a caracterização ou, simplesmente, não conseguiram avaliar a fala rural sob esse aspecto repetindo, assim, o comportamento já percebido no teste anterior -, 33\% consideraram-na bonita e 8\% como feia. Em relação ao modelo urbano, $28 \%$ não o avaliaram - percebese, pois, um percentual bem menor que a negação anterior, o que dá subsídios para sustentar a tese de abstenção da autoavaliação -, 69\% declararam-no como bonito e 2,6\% como feio. Considerando que o urbano utilizado no teste foi o próximo ao carioca, o resultado dialoga com os de tantas outras pesquisas no Brasil que admitem ser esta a variedade 
mais bem aceita e considerada a padrão e, por consequência, a melhor avaliada pela população (CARDOSO, 2015, p.72).

Analisando as atitudes dos falantes à luz da variável faixa etária, verifique-se que para ambas as gerações, $78 \%$ dos pais e avós e $62 \%$ dos jovens, a fala urbana é considerada mais bonita se comparada à rural. Quando a valoração é negativa, tem-se o seguinte resultado: $11 \%$ da geração 1 (mais velhos) caracterizam como feia a fala rural e nenhum vê a urbana dessa forma; $5 \%$ dos jovens adjetivam os dois modelos como feios. Fato interessante é o alto percentual dos informantes que abdicaram desse julgamento: $61 \%$ dos mais velhos não avaliaram a fala rural e $22 \%$ a urbana; $57 \%$ dos estudantes não julgaram o exemplar rural e 33\% o urbano, confirmando o diagnóstico anterior.

Resultados um pouco menos discrepantes, mas indicando uma mesma direção de análise, podem ser percebidos na variável sexo. No que se refere ao áudio urbano: $25 \%$ das mulheres não o avaliaram sob tal aspecto, assim como 32\% dos homens; $70 \%$ delas e $68 \%$ deles o julgaram bonito; e apenas $5 \%$ das representantes do grupo feminino o acharam feio. Já em relação ao rural, os números se invertem e a atitude dos informantes é menos condescendente. Assim, $50 \%$ das mulheres e $68 \%$ dos homens não o avaliaram; $35 \%$ delas e $32 \%$ deles o veem como bonito; e $15 \%$ delas 
alegaram que a fala rural é feia, enquanto nenhum deles a avaliou assim. A atitude menos positiva ou negativa das mulheres, em comparação aos homens, diante do áudio de sua própria variedade foi também detectada por Cardoso em Aracaju (CARDOSO, 2015, p.62). A autora detectou "uma forte tendência das mulheres na observação das normas linguísticas, confirmando assim o padrão geral do fator sexo: as normas linguísticas estão mais associadas às mulheres do que aos homens." (CARDOSO, 2015, p.116).

De forma geral, em todos os cruzamentos de dados o modelo urbano despertou uma atitude mais positiva dos entrevistados, diferentemente do rural que ou não foi avaliado ou obteve respostas mais exigentes de seus próprios usuários. O resultado aqui aponta uma concordância com o 4o princípio, criado por Labov, para o estudo de reações subjetivas de Lamblet (1967). O sociolinguista, ao estudar a avaliação dos nova-iorquinos, concluiu que "Falantes que exibem o mais alto índice de uso de um traço estigmatizado em sua própria fala espontânea apresentam a maior tendência a estigmatizar os outros pelo uso dessa mesma forma" (LABOV, 2008, p.357).

Por enquanto, o resultado obtido corrobora a hipótese de Hora e Lopes sobre o julgamento das regionalidades, quando investigaram a percepção da população a respeito 
da fala empregada em telejornais: "a ocorrência de variantes linguísticas regionais pode ser associada a atitudes menos positivas do ouvinte em relação ao falante, levando-se em consideração aspectos estilísticos e de estigmatização." (HORA e LOPES, 2015, p.74)

Desse modo, ainda no campo da afetividade contemplativa e usando os mesmos critérios de valoração da análise em ausência, procurou-se saber dos entrevistados qual dos áudios lhes parecia mais agradável. Em percentuais gerais, sem cruzamento de variáveis, $26 \%$ dos entrevistados não avaliaram a fala rural e 23\% a fala urbana; $72 \%$ afirmaram que ambas as falas são agradáveis; $2 \%$ consideraram o falar rural desagradável e 5\% o urbano.

Levando em conta a variável faixa etária, percebem-se reações um pouco distintas daquelas apontadas no resultado geral. Da geração 1: 33\% dos informantes não quiseram avaliar, sob esse ponto de vista, nenhum dos dois áudios; $61 \%$ veem o modelo rural como agradável e 56\% o urbano; $6 \%$ entendem como desagradável o rural e $11 \%$ o urbano. Da geração 2: 19\% se mantiveram neutros em relação ao rural e $14 \%$ ao urbano; $81 \%$ compreendem que a fala rural é agradável e $86 \%$ a urbana; e nenhum deles considerou quaisquer áudios como desagradáveis. Parece, portanto, que para os jovens há um menor estranhamento em relação 
ao modelo exógeno do que para os adultos, que são tão mais críticos no que se refere a sua variedade quanto menos receptivos com a outra variedade.

Fato semelhante ocorre no gênero feminino, já que as mulheres se desobrigaram menos dessa avaliação do que os homens (32\% deles não avaliaram nenhum dos dois áudios, 20 \% delas não o fizeram com a fala rural e 15\% com a urbana) e consideraram a fala urbana (85\%) mais agradável do que a rural (75\%). Outro índice interessante é que para $10 \%$ dos homens a fala urbana foi caracterizada como desagradável, enquanto que nenhuma das mulheres a considerou assim. O fator agradável, portanto, indicou principalmente, para os mais velhos muito mais um autorreconhecimento e um sentir-se bem com esse reflexo do que uma apreciação estética meramente.

Em se tratando dos estratos sociais, procuraram-se estigmas ou valorizações de acordo com a consideração dos seguintes aspectos: classe social, escolaridade e idade, pois, por muitas vezes, os entrevistados associaram a fala rural aos moradores mais antigos e com menos acesso à instrução formal. Desse modo, os resultados vão ser assim dispostos.

No que tange à classe social, eram, a princípio duas possibilidades de classificação comparativa: + rico e + pobre. Todavia, durante as entrevistas, outros dois critérios surgiram 
como possibilidade de análise: classe média e não sujeito à avaliação. Assim, a classe baixa foi associada à fala rural por $49 \%$ dos entrevistados e à urbana para 2,5\%. Já a classe alta esteve relacionada ao rural em $13 \%$ dos inquéritos e ao urbano em $64 \%$ deles. $10 \%$ dos informantes avaliaram tanto um modelo quanto o outro como pertencentes a pessoas de classe média. A avaliação não foi realizada em $28 \%$ das audições da fala local e $23 \%$ daquela de origem externa.

O diagnóstico se torna mais explícito com as respostas da faixa etária 2. Nenhum dos jovens considerou a falante urbana como pobre, mas 78\% consideraram-na rica. Na geração 1, os índices foram menos antagônicos, pois aqui o rural se relacionou à classe baixa em 56\% das audições e o urbano à classe alta em $61 \%$ delas. Na variável sexo, o resultado se manteve sem mostrar grande alteração entre homens e mulheres. No entanto, as distorções entre as classes sociais foram menores: $50 \%$ das mulheres entenderam a fala rural como a de um indivíduo pobre, assim como $47 \%$ dos homens; e $65 \%$ delas e $63 \%$ deles relacionaram a fala urbana à classe alta.

Indicia-se, pois, com esse resultado, mais um estigma. Para os próprios usuários da variedade em análise, a fala rural pertence a indivíduos pobres e a urbana àqueles com poder aquisitivo alto, o que de fato não corresponde à realidade, 
uma vez que, se levadas em conta as condições materiais das famílias pesquisadas, a pobreza não é um atributo que Ihes confere. As famílias não se encaixam na classe alta, mas em sua grande maioria, moram em casas próprias, possuem, pelo menos, dois meios de transporte particulares, acessam a internet de casa e, segundo suas afirmações, têm um certo conforto em suas moradias, fruto de um trabalho duro "na roça".

No quesito escolaridade, diagnosticou-se que, para os entrevistados:

- O áudio rural é de uma pessoa: sem estudo, para 69\%; com escolarização, para 5\%; com escolarização baixa, para $20 \%$. Os outros $5 \%$ não conseguiram avaliar a fala segundo esse critério. Portanto, se somadas as duas possibilidades de resposta de carga negativa, ter-se-ia, então, $89 \%$ dos entrevistados associando o rural com o baixo ou o nenhum nível de escolaridade.

- O exemplar urbano pertence a um sujeito: sem instrução formal, para 2,5\%; escolarizado, para 85\%; com pouca escolaridade, para 2,5\%. O restante dos informantes, $10 \%$, não soube fazer esse julgamento.

Na variável faixa etária $1,78 \%$ de pais e avós relacionaram tanto a fala rural com a falta de escolaridade quanto a urbana com um alto nível de escolarização. Nenhum deles classificou 
o modelo urbano como sem estudo. Já na geração 2, para $90 \%$ dos jovens, o falar urbano é de um cidadão muito escolarizado e, para $62 \%$, o rural corresponde à falta de instrução. O que muda aqui é o fato de os estudantes não se negarem a avaliar esse critério e terem compreendido com média escolaridade o representante da zona rural, o que não ocorreu entre os mais velhos. Nesse aspecto, a estigmatização recai com maior força sobre a geração mais nova.

Quando a variável sexo é destacada, para as mulheres a desproporção entre o rural e o urbano é ainda maior no que se refere ao nível de escolaridade, já que $75 \%$ delas acreditam que o primeiro modelo é de uma pessoa sem estudo e 90\% afirmaram que o segundo é de uma pessoa altamente escolarizada. Para os homens, a porcentagem é mais próxima, $63 \%$ para aquele e $70 \%$ para este.

A percepção de idade dos falantes-modelo se torna um fator importante a ser analisado, pois foi comum, em vários depoimentos, a associação entre a fala local, considerada "errada", como pode ser percebido na avaliação em ausência, e os moradores mais antigos, que também são aqueles que não tiveram acesso sistemático à escola. Cabe reiterar que as duas falas que serviram de estímulo pertenciam a mulheres com aproximadamente a mesma idade.

Efetivamente, tal juízo se confirmou na análise em presença. Para 69\% dos entrevistados o áudio modelo de fala 
rural correspondia a uma falante mais velha e o exemplar urbano pertencia, para $74 \%$ dos informantes, a uma mulher mais nova. Os percentuais foram praticamente os mesmos quando se considerou a variável faixa etária: $72 \%$ dos pais e avós e $67 \%$ dos jovens relacionaram a fala rural a uma pessoa de mais idade e também $72 \%$ do primeiro grupo e $76 \%$ do segundo vincularam o modelo urbano a uma faixa etária menor. Na variável sexo, notou-se que as mulheres foram mais incisivas nessa questão, pois $80 \%$ acreditaram estar diante da fala de uma pessoa mais velha no áudio rural e de uma mulher mais nova no modelo urbano. Vale destacar que nenhuma delas deixou de considerar tal critério. Já para $58 \%$ dos homens o falar rural foi combinado a uma pessoa mais velha, enquanto $68 \%$ ligaram o tipo urbano a uma faixa etária mais baixa.

Por fim, a questão identitária foi colocada em xeque. $\mathrm{O}$ último item do questionário com áudio estímulo pretendia diagnosticar se a comunidade reconheceria sua própria variedade. $95 \%$ dos informantes consideraram familiar o modelo rural apresentado, afirmando que ele era, por certo, de uma moradora da região, indo de encontro, portanto, à conclusão que chegara Labov (2008, p.161) ao afirmar que os falantes nova-iorquinos de fala estigmatizada percebiam sua intenção fônica, próxima ao modelo prestigiado, e não 
de fato o som que produziam. Apenas $26 \%$ ponderaram que o exemplo urbano também não era estranho e que poderia pertencer a uma nativa. Todavia, para $64 \%$ dos entrevistados a última fala era estranha ao seu convívio.

Merecem ressalva dois tópicos no cruzamento das variáveis: $100 \%$ dos homens e $100 \%$ da faixa etária 2 reconheceram a fala local. Isso não significa que os mais velhos e as mulheres não se tenham reconhecido em sua maioria, uma vez que $89 \%$ da geração 1 e $90 \%$ das mulheres também o fizeram. Destarte, pode-se, enfim, afirmar que, de fato, a partir de uma abordagem direta das reações dos falantes das próprias variáveis (LABOV, 2008, p.191), existe uma variedade linguística local e uma identidade social na região forjada por essa língua. Ambas são reconhecidas como tal pela comunidade, embora, muitas vezes, essa variação diatópica seja estigmatizada pelos seus próprios usuários, sobretudo, as mulheres mais velhas.

\section{CONSIDERAÇÕES FINAIS DAS CONVERGÊNCIAS E DIVERGÊNCIAS: O CRUZAMENTO DOS TESTES E DOS DADOS TESTADOS}

A avaliação em ausência e o teste com áudio modelo não demonstraram discrepâncias em relação às atitudes e aos julgamentos dos informantes. Em linhas gerais, as análises caminharam para uma mesma direção. Todavia, a conclusão 
sobre os eventos aqui descritos pode ser ainda mais refinada em uma metodologia de aproximação eclética (CARDOSO, 2015, p.115), buscando, para isso, possíveis divergências e convergências mais estreitas entre os dados recolhidos e os resultados aqui encontrados.

Essencialmente, comprovou-se que realmente há uma aceitação de variação diatópica na região pesquisada, ainda que com pequenas percepções de nuances na distribuição do território. A maioria dos sujeitos testados confirmou essa premissa na avaliação em ausência e pôde reafirmar a asserção, ainda com mais certeza, na identificação do áudio modelo de fala rural, corroborando a pesquisa de Cardoso (2015) em relação à autoavaliação linguística dos aracajuanos e refutando a premissa de Labov (2008) para quem os falantes relacionam sua fala a um modelo de prestígio. Os percentuais nessas duas questões foram, praticamente, idênticos. No primeiro 94,9\% dos sujeitos testados afirmaram haver uma fala típica da região e, no segundo, 95\% deles identificaram o áudio correspondente a essa variedade. Do mesmo modo, ainda que alguns moradores não tenham se reconhecido como falantes da variedade local, cerca de $23 \%$, grande parte indicou que aquela fala ouvida era como a deles ou como a que eles estavam acostumados a lidar. 
Em relação à avaliação estética, quando comparados os dois tipos de testagem, houve mudança de atitude frente ao objeto analisado. Em ausência, 44\% dos informantes afirmaram ser a variedade da região bonita, enquanto 33\% a avaliaram da mesma maneira em presença do áudio, dialogando, desse modo, com os resultados obtidos por Cardoso (2015), nos quais a avaliação em ausência também foi mais positiva. Todavia, o índice negativo também foi reduzido, visto que $18 \%$ a consideraram feia, inicialmente, e apenas $8 \%$ mantiveram sua opinião depois de ouvi-la. 0 que de fato mudou foi o percentual de não avaliação, que subiu de $39 \%$ para $59 \%$. No momento em que a fala passou a ser personificada, passou a pertencer a alguém, houve uma maior dificuldade em julgá-la.

Resultado exatamente oposto foi detectado no que se referiu à agradabilidade da fala. Em ausência, 46\% dos entrevistados, ainda a maioria, julgaram sua variedade como agradável. Já em presença, o percentual subiu para $72 \%$. Em ambos os casos com representatividade maior entre jovens. Entretanto, quando se analisa o gênero, as mulheres foram maioria com a audição e a minoria sem ela. $O$ índice desagradável então caiu de $10 \%$, no primeiro teste, para quase $4 \%$ no segundo. As abstenções que representavam $44 \%$ dos indivíduos também sofreram grande queda, passando a $24 \%$. 
Aqui o que se pode concluir é que, com o áudio, houve maior percepção identitário-linguística e a fala soou mais familiar aos entrevistados. Eles se mostraram muito incomodados com a "quantidade de _s" da representante urbana. Foi comum associarem as concordâncias nominais empregadas no modelo urbano a uma fala forçada e pouco natural, o que Ihes desagradou, como pode ser observado abaixo:

\begin{tabular}{|c|l|}
\hline INFOR. & FALA \\
\hline 26 & Num sei, acho que ela puxa um cado no esse ( ) \\
\hline
\end{tabular}

Outro critério avaliativo que pode ser compreendido em conjunto foi o fato de a fala local ter sido justificada a partir da idade e da escolaridade de seus usuários. $\mathrm{Na}$ primeira parte do inquérito metalinguístico, um dos motivos apresentados como uma possível explicação para a comunidade empregar aquela variedade foi a falta de estudo e de relação com outros ambientes de convivência externos dos moradores mais antigos. Essa percepção foi confirmada na segunda parte do inquérito, na qual $89 \%$ dos entrevistados asseguraram que a fala rural pertencia a alguém com pouco ou nenhuma escolarização e quase $70 \%$ garantiram que era de uma pessoa mais velha do que a representante urbana. Nesse sentido, tem-se uma contradição desses dois resultados, se comparados ao reconhecimento da própria fala, já que $66 \%$ dos jovens, que são também os de maior 
instrução, afirmaram ainda falar como a comunidade. Em conclusão semelhante, Cardoso percebeu que "a língua culta tem mais importância para aqueles que menos a utilizavam" (CARDOSO, 2015, p.88) e "quanto mais os informantes são instruídos mais eles concordam em declarar que 'falar bem significa falar como o povo'" (CARDOSO, 2015, p.89).

No entanto, no processo de reconhecimento residem também outras compreensões. Embora se identifiquem com a variedade regional são os jovens que apresentaram maior índice de mudança e adequação de fala devido ao contexto comunicativo. Como já mencionado anteriormente, a necessidade de aderência a outros grupos sociais faz com que o jovem adapte à sua fala. Em relação a isso, Labov afirma que:

Em toda comunidade existem falantes que têm mais consciência do que outros das formas prestigiosas de fala e cujo comportamento é mais influenciado pelos padrões externos de excelência. Eles exibirão uma alternância estilística maior do que aqueles que não reconhecem tais padrões. (LABOV, 2008, p.251)

A troca de estilos só pode ser posta em prática por indivíduos que identificam as variantes, incluindo a de prestígio, e que têm condições de colocá-las em uso nas 
situações comunicativas. Labov lembra que o fenômeno é observado com mais frequência em indivíduos mais escolarizados e aí chama a atenção para o fato de que a entrevista é um evento formal e que, portanto, esses mesmos sujeitos podem, ao ser entrevistados, acionar uma variante que não a sua habitual:

Normalmente, o pesquisador fala o dialeto-padrão superordenado que é dominante nessa situação de entrevista face-a-face. A capacidade do informante de aprender línguas está operando o tempo todo, e é sabido que suas regras gramaticais ficarão sob pesada influência do padrão durante este período de elicitação. (LABOV, 2008, p.250).

Como, no caso desta pesquisa, a pesquisadora era, ou já tinha sido, também a professora de Língua Portuguesa dos jovens entrevistados, é possível que eles, além de terem tentado adequar sua fala àquela situação de formalidade, tenham respondido idealmente a certas questões. Como todo evento interativo é responsivo, ou seja, motivado pela audiência (HORA e LOPES, 2015; LABOV, 2008), não há maneiras de evitar tal interferência nem condições para criar hipóteses sobre o grau de influência dessa situação. O fato é que o jovem acaba também por assumir inúmeras identidades que, por sua vez, são desveladas e moldadas 
na própria linguagem. Todavia, essa não parece ser uma prática democratizada, já que, pelos resultados, não está tão acessível e nem é realizada com frequência pelos mais velhos.

\section{REFERÊNCIAS}

BASTOS, Liliana Cabral; LOPES, Luiz Paulo da Moita (Orgs.) (2011). Estudos de identidade: entre saberes e prática. Rio de Janeiro: Garamond.

BORTONI-RICARDO, Stella Maris (2011). Do campo para a cidade: estudo sociolinguístico de migração e redes sociais. São Paulo: Parábola Editorial.

(2014). Manual de Sociolinguística. São Paulo: Contexto.

(2005). Nós cheguemu na escola, e agora?: sociolinguística e educação. São Paulo: Parábola Editorial.

CARDOSO, Denise Porto (2015). Atitudes linguísticas e avaliações subjetivas de alguns dialetos brasileiros. São Paulo: Blucher.

COMERFORD, John Cunha (2005). "Comunidade Rural". In: MOTTA, Márcia. (Org.). Dicionário da Terra. Rio de Janeiro: Civilização Brasileira.

ECKERT, Penélope; MCCONNELL, Sally (2010). "Comunidade de prática: lugar onde co-habitam linguagem, gênero e poder." In: OSTERMANN, Ana Cristina; FONTANA, Beatriz (Orgs.). Linguagem, gênero e sexualidade: clássicos traduzidos. São Paulo: Parábola Editorial.

FRAZÃO, Gabriel Almeida (2015). "A serviço da formação do jovem rural": desafios e contradições na atuação do CEFFA CEA Rei Alberto I como agente do desenvolvimento do meio. (Tese - Doutorado) - CPDA, Universidade Federal Rural do Rio de Janeiro, Rio de Janeiro.

FREITAG, Raquel Meister Ko (Org.) (2014). Metodologia de coleta e manipulação de dados em sociolinguística. São Paulo: Blucher.

; SEVERO, Cristine Gorski (Orgs.) (2015). Mulher, linguagem e poder: estudos de gênero na sociolinguística brasileira. São Paulo: Blucher. HORA, Dermeval da; LOPES, Leonardo Wanderley (2015). "Atitude do ouvinte versus estilo e variação do falante." In: SEVEDRA, Mônica Maria Guimarães; MARTINS, Marco Antonio; HORA, Dermeval da. (Orgs). 
Identidade social e contato linguístico no português brasileiro. Rio de Janeiro: FAPERJ/EdUERJ.

LABOV, William (2008). Padrões sociolinguísticos. São Paulo: Parábola Editorial.

LUCCHESI, Dante (2015). Língua e sociedade partida: a polarização sociolinguística no Brasil. São Paulo: Contexto.

OLIVEIRA, Victor Pereira de (2011). Repensando o rural sob o prisma das urbanidades, em Nova Friburgo, RJ. Curitiba, PR: CRV.

PEIRANO, Mariza (2014). Etnografia não é método. Horizontes Antropológicos, Porto Alegre, 20(42), 377-391.

SEVERO, Cristine Gorski (2007a). Por uma perspectiva social dialógica da linguagem: repensando a noção de indivíduo. (Tese - Doutorado) Universidade Federal de Santa Catarina, Florianópolis.

(2007b). A questão da identidade e o lócus da variação/mudança em diferentes abordagens sociolinguística. Revista Letra Magna, 4(7).

Jaqueline de Moraes Thurler Dália é Doutora em Estudos da Língua Descrição da Língua Portuguesa (UERJ) e Mestra em Educação Agrícola (UFRRJ). Professora de Língua Portuguesa e Literatura do Instituto Federal Fluminense - Campus Cambuci. Coordenadora e professora da PósGraduação Lato Sensu em Literatura, Memória Cultural e Sociedade do Instituto Federal Fluminense - Campus Cambuci. Tem como principais produções: a) artigos completos em periódicos - A trajetória dos estudos sociolinguísticos e suas possíveis abordagens: caminhos paralelos na encruzilhada das pesquisas. Web-Revista Sociodialeto, v.6, p.118, 2016; As vozes verbais na gramaticografia brasileira. Revista Philologus, v.1, p.27-41, 2013; b) capítulos de livros - DÁLIA, J. M. T.; FRAZÃO, G. A. Para além do Ensino Integrado: experiências, possibilidades e desafios da articulação entre ensino, pesquisa e extensão no currículo. In Adilson Cesar Araújo e Cláudio Nei Nascimento da Silva. (Org.). Ensino Médio Integrado no Brasil: fundamentos, práticas e desafios. 1ed. Brasília: IFB, 2017, p.166-183; e DÁLIA, J. M. T.; FRAZÃO, G. A. A Pedagogia da Alternância no Estado do Rio de Janeiro: relação entre Ceffas, comunidades e o poder público. In Iranilde de Oliveira Silva; Lia Maria Teixeira de Oliveira; Monica A. Del Rio 
Benevenuto. (Org.). Cadernos de discussão: juventude, educação do campo e agroecologia. Rio de Janeiro: Outras Letras, 2011, p.137-154; c) livros: FRAZÃO, G. A.; DÁLIA, J. M. T. Políticas Públicas e Organização da Educação do Campo: reflexões sobre a construção e o desenvolvimento dos CEFFAs fluminenses. 1.ed. NEA, 2013. 80p. Participa dos seguintes grupos de pesquisa: Núcleo de Estudos e Pesquisas em Pedagogia da Alternância, Educação do Campo e Ensino de Agroecologia - UFRRJ, na linha de pesquisa Políticas Públicas, Educação do Campo e Movimentos Sociais; e Núcleo de pesquisas e estudos sobre as ruralidades fluminenses - IFF, na linha de pesquisa Linguagem, Identidade e Memória do Rural Fluminense. E-mails: jaquelinethurlerdalia@gmail.com e jaqueline.dalia@iff.edu.br. 